\title{
Anal itching
}

Figures 1-3 in this Practice (BMJ 2016;355:i4931, doi:10.1136/ bmj.i4931) were published online under the wrong captions.

This has been now been corrected. 